\title{
A TUdOMÁNYOS SZAKKÖNYVTÁRAK ÉS A NYÍLT TUdomány (Open Science)
}

\section{Holl ANDRÁs}

A nyîlt tudomány a kutatás és a tudományos kommunikáció különböző, nagyobb átláthatóságra törekvő módszertani területeit átfogó gyűjtőfogalom. Mindenképpen ennek körébe tartozik a nyílt hozzáférés (Open Access) és a kutatási adatok nyílt kezelése (Open Research Data). Ez utóbbinál újabban nem a nyílt, hanem a FAIR jelzőt alkalmazzák. A nyílt kutatási munkafolyamatok kevésbé fejlettek, a nyílt bírálati eljárások (Open Peer Review) ugyanakkor gyorsan fejlődnek. A nyílt tudomány összekapcsolódott néhány, eredetileg különálló területtel is, mint a nyílt forráskódú szoftverek (a tudomány műveléséhez kapcsolódó részük), a nyílt oktatási lehetőségek, vagy a közösségi tudomány (Citizen Science).

Az Open Science taxonómiája a FOSTER ${ }^{1}$ projekt szerint:

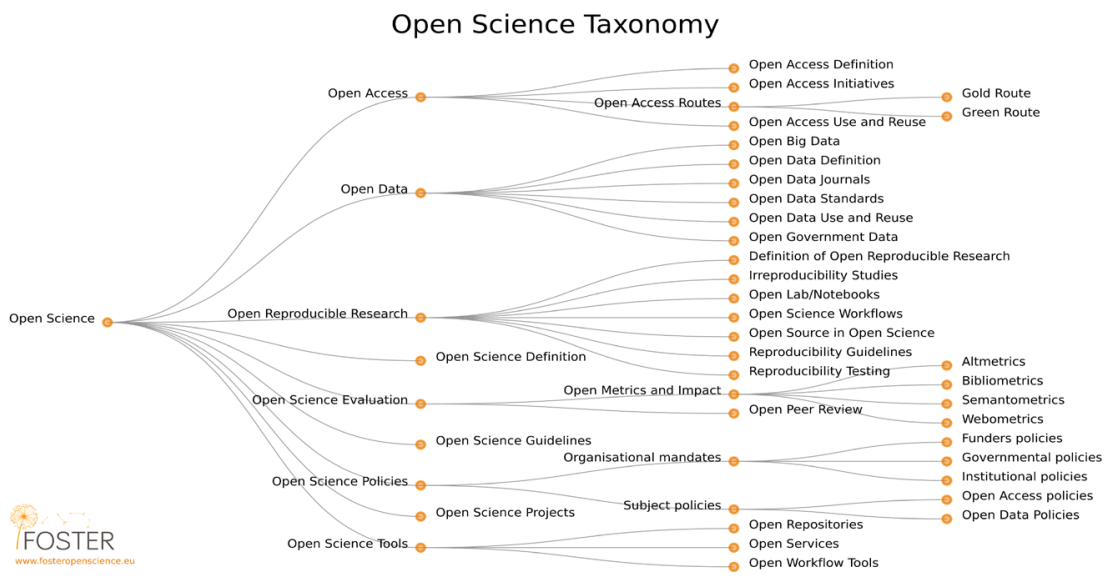

1 https://www.fosteropenscience.eu/ (utolsó megtekintés: 2021. 09. 23.) 
A nyílt tudományra szükség van, mert

- az exponenciálisan bővülő tudomány menedzselhetőségét, finanszírozhatóságát fenn kell tartani;

- szükség van a tudomány iránti állampolgári bizalom erősítésére;

- biztosítani kell a tudományos kutatók utánpótlását;

- csökkenteni kell a fejlődő országok lemaradását;

- növelni kell a tudomány társadalmi és üzleti hasznosulását;

- növelni kell a hatásfokot (egységnyi ráfordításból több eredményt kell elérni);

- és legfőképpen jobb minőségbiztosításra van szükség: növelni kell a reprodukálhatóságot.

Másként fogalmazva: az alapvető célok a kutatási eredmények verifikálhatóságának erősítése, a kutatási eredmények újrafelhasználhatóságának bővítése és a tudomány transzparenciájának növelése. A tudományos alapkutatás célja, hogy az eredményeit alkalmazzák mind további kutatásokban, mind a gyakorlatban. A kutatók karrierjének alapvető értékelése munkájuk felhasználásán, idézettségén alapul. Nem célszerű a kutatási eredmények terjesztésének útjába akadályokat állítani.

A tudományos szakkönyvtárak a nyílt tudomány elsőnek kialakult területén, a nyílt hozzáféréssel foglalkoznak leginkább. A Budapest Open Access Initiative (BOAI) ${ }^{2}$ fogalmazta meg a nyílt hozzáférés két lehetséges útját - ezek közül a repozitóriumi (zöld) út esetében a könyvtárak lehettek a szolgáltatások megvalósítói (noha az 1990-es években, még az OA mozgalom előtt indult arXiv kutatói kezdeményezés volt). A könyvtárak oldaláról jelentkezett a legerősebb motiváció is: a folyóirat-előfizetések egekbe szökő költségei. (Azt még nem lehetett látni akkoriban, hogy az APC-k kezelése is könyvtári feladat lesz.)

A nyílt tudomány jelenleg inkább egy célkitűzés, egy elképzelés, mint

2 https://www.budapestopenaccessinitiative.org/ (utolsó megtekintés: 2021. 09. 23.) 
mindennapi gyakorlat. A nyílt hozzáférés is erősen változik, fejlődik, pedig ez a részterület már majdnem két évtizedes múltra tekint vissza (amennyiben a BOAI-tól számítjuk). A nyílt kutatási adatok tekintetében és más területeken a nyílt tudomány éppen egy „bootstrap” fázisban van; a kutatói közösség saját gyakorlatát kell magasabb szintre emelnie anélkül, hogy ennek szilárd támaszai lennének (pl. kialakult szabványok, módszerek). A nyílt tudomány módszereit, eszközeit és szabványait „menetből” kell kifejleszteni.

Akkor lehet sikeres a nyílt tudomány, ha alapelvei és gyakorlata szervesen integrálódnak a kutatási ciklusba. Meg kell ebben a folyamatban találni a könyvtárak szerepét is - mint ahogy a korábbi paradigmákra alapozott kutatási ciklus esetében is történt.

A nyílt tudomány alapvetően digitális környezetben, informatikai eszközök használatával végezhető. (Egyfelől mára egyre inkább digitalizálódik az emberi tevékenység minden vetülete, másfelől a hozzáférés és az újra-felhasználás lehetőségei a digitális technikák alkalmazásával új szintre léptek. Kulcstechnológiái közül az egyik az állandó azonosítók (persistent identifiers, PID) ${ }^{3}$ használata. Ezek az azonosítók végigkísérik a digitális objektumok életét, és alkalmasak arra, hogy segítségükkel az emberi vagy gépi felhasználó eljuthasson az objektumhoz. Sokféle állandó azonosító létezik, a későbbiekben azonban csak a legelterjedtebbel, a Digital Object Identifier-rel (DOI) foglalkozunk.

A nyílt tudomány nem működtethető anyagi háttér hiányában. A szolgáltatásokból hasznot húzó közösségnek támogatnia kell a kiszolgáló infrastruktúrák működtetését - a támogatások szervezését végzi a Global Sustainability Coalition for Open Science Services (SCOSS).

3 https://www.dpconline.org/handbook/technical-solutions-and-tools/ persistent-identifiers (utolsó megtekintés: 2021. 09. 23.) 


\section{A tudomÁnYos SZAKKöNYVTÁrAK ÉS A NYÍLT HOZZÁFÉRÉS (Open Access)}

Nemigen akad olyan nézete a nyílt hozzáférésnek, ahol a könyvtárak ne lennének érdekeltek. Kezdve a kutatók, olvasók tájékoztatásától, képzésétől a repozitóriumok működtetésén és a publikálási díjak (APC) kezelésén át egészen a tudományos könyv- és folyóirat-kiadásig.

A nyílt hozzáférés alapjait illetően Sauber (2012) alapművét ajánljuk tájékozódásra, a könyvtári feladatokat és problémákat pedig Holl (2018a) tárgyalja részletesen.

\section{1.) TÁjÉKOZTATÁS, KÉPZÉS}

A szakkönyvtárak olvasószolgálatosainak át kell alakítaniuk működésüket, mivel az olvasók (kutatók, oktatók, egyetemi hallgatók) által igényelt szakirodalom egyre nagyobb mértékben elérhető nyílt forrásokból. Nem sok beavatkozást igényel részükről az a tény, hogy az általuk előfizetett indexelő rendszerekben (WoS, Scopus) a szabadon olvasható tartalmak száma nő. Fontosabb változás, hogy ezen a piacon új szereplők tűntek fel (Dimensions, Lens, Microsoft Academic stb.). Megjelentek azok az eszközök, amelyek a böngészőkbe telepítve megtalálják a fizetôs tartalmak repozitóriumokban szabadon elérhető kópiáit (Unpaywall). Ilyen technológiát használ a cikkek DOI alapon való keresésére az EISZ COMPASS is. És megjelentek az „akadémiai” közösség által fenntartott, szabadon használható kereső-aggregátorok, mint a Jisc CORE és a BASE. (Hazai közös kereső az MTA KIK és a SZTAKI által működtetett http://oaikereso.sztaki.hu/.)

Sok könyvtár kínál olvasóinak egyablakos keresőt. Itt fontos szempont, hogy a kereső indexelje a szabad tartalmakat - elsősorban a saját repozitórium tartalmait.

További, a repozitórium üzemeltetéssel összefüggő feladat a zárolt dokumentumok helyben olvasásának technikai és jogi feltételeit megteremteni. 
Hasonlóan fontos az egyetemi hallgatók, oktatók és kutatók számára a nyílt hozzáféréssel is foglalkozó képzés. Része a tájékoztatási feladatoknak a nyílt hozzáférés élősködőinek (parazita vagy predátor folyóiratok, Holl 2020b) ismertetése, vagy a nyilvántartások nyomon követése.

\section{2.) RePOZitóRIUMOK}

$\mathrm{Az}$ Open Archives Initiative nyomán létrejött, PMH protokollt alkalmazó repozitóriumok üzemeltetése a tudományos szakkönyvtárak alapvető feladatává vált. Bár más digitális könyvtári platformok is elképzelhetők, jelenleg semmilyen IKR, semmilyen más CMS rendszer nem tudja azokat a funkciókat megvalósítani, ami egy repozitóriumi szoftvertől elvárt:

- OAI-PMH protokoll támogatás

- SWORD protokoll támogatás

- flexibilis felhasználói feltöltési lehetőség

- embargó alkalmazásának lehetősége

- széles felhasználói-üzemeltetői közösség.

Csak akkor tudják jól teljesíteni feladataikat a repozitóriumok, ha a könyvtár gondoskodik bekapcsolásukról a különböző hálózatokba (szolgáltatólisták [registry], aggregátorok) - ennek gyakorta feltétele tanúsítványok beszerzése.

Azon túl, hogy az aktív kutatók publikációihoz való nyílt hozzáférést megvalósítják, az intézményi digitalizálási programok eredményeinek tárolására is alkalmasak. Amennyiben a könyvtár DOI azonosítók szolgáltatásával is foglalkozik, a repozitórium funkcionálhat elsődleges tartalomszolgáltatóként (pl. saját webes szolgáltatással nem rendelkező, vagy a könyvtár által kiadott publikációknak), vagy másodlagos, biztonsági archívumként. 
A szoftverüzemeltetésen túl a repozitórium-üzemeltetés további állandó feladatokat is jelent a könyvtáraknak. Fontos a gyarapítási folyamatban a könyvtárosi kontroll: ügyelni kell a feltöltött állományok minőségére, a megfelelő metaadatokra, a kiadói jogokra stb. A repozitóriumokat össze kell kapcsolni különböző, a könyvtár által működtetett (vagy külső) rendszerekkel: IKR, egyablakos kereső, CRIS rendszer (Magyarországon az MTMT).

A repozitóriumnak a könyvtár egyik alapvető szerves részegységének kell lennie, szerepelnie kell az SZMSZ-ben, személyi és költségvetési erőforrásokkal kell rendelkeznie. Ezt elősegíti a repozitórium minősítése is - hazai lehetőség erre az MTMT repozitórium-minősítő bizottsága által adott tanúsítvány. Egyúttal a repozitóriumnak illeszkednie kell az országos és nemzetközi hálózatokba. Ajánlatos a HUNOR tagság az üzemeltetőnek, technikailag be kell jegyezni a repozitóriumot különböző lajstromokba - enélkül, illetve minősítések híján nem tudja hatékonyan láthatóvá tenni a tartalmait.

A repozitórium lehet az eszköz a különböző intézményi vagy projektdokumentációk megőrzésére és közzétételére. A szürke irodalom körébe tartoznak a disszertációk is, ezek közül a PhD disszertációkról a felsőoktatási törvény is rendelkezik. (Az MTA doktori disszertációi 2010-től kötelezően, a korábbi doktori és kandidátusi disszertációk igény és engedély esetén a REAL-d-be kerülnek, egyes szerződött, jellemzően kisebb egyetemek $\mathrm{PhD}$ dolgozatai pedig megállapodás alapján a REAL-PhD-be.)

A repozitóriumok hosszútávú megőrzési feladatának teljesítéséhez elsősorban az üzemeltető intézménynek kell megteremtenie a feltételeket. Ezek közé sorolhatjuk a stabilitást (szabályozás, költségvetés, munkaerő), a technikai biztonságot (mentés, monitorozás, behatolásvédelem stb.). Mindazonáltal előfordulhat, hogy a repozitóriumot működtető intézmény vagy maga a repozitórium megszűnik. Erre a helyzetre ad biztonságot a tartalmak megosztása és a végrendelet ( $k i$ veszi át a tartalomszolgáltatást megszűnés esetén). Ez 
utóbbi persze akkor működik biztonságosan, ha a tartalmak lemásolása (sötét archívumként) folyamatos.

\section{3.) KÖZLÉSI dÍJAK (APC) MENEDZSELÉSE}

A tudományos szakkönyvtárak feladata az elektronikus tartalmak (pl. folyóiratok, e-könyvek) előfizetése. Az előfizetések kezelésében mára fontos szempont lett az OA és az APC kérdése. Az előfizetési döntések meghozatalára kínál segítséget a hazai szakkönyvtáraknak a COMPASS+.

Az intézmény kutatói több különböző csatornán keresztül fizethetnek közlési díjakat (Article Processing Charge, APC). Egyrészt fontos könyvtári feladat a Read and Publish szerződésekben szereplő lehetőségekről való tájékoztatás a kutatóknak, másfelől meg kell kísérelniük a szerződéseken kívül történt APC kifizetések nyilvántartását.

\section{4.) RÉSZVÉTEL A FOLYÓIRAT- ÉS KÖNYVKIADÁSBAN}

A tudományos szakkönyvtárak külföldön (pl. az UCL) és Magyarországon egyaránt (SZTE, DE, MTA KIK stb.) folytatnak kiadói tevékenységet is. Ehhez gyakorta használják az OJS platformot (esetleg az OCS-t vagy OMP-t). Előfordul az is (pl. MTA KIK), hogy szoftverplatformot biztosítanak más kiadók által kiadott folyóiratoknak. A könyvtár érdekeltsége ez esetben az lehet, hogy a saját platformon vendégül látott tartalmak archiválásra kerülhetnek a repozitóriumban, kereshetők a könyvtári egyablakos keresőben, illetve a könyvtári DOI szolgáltatás is kapcsolatot jelenthet.

A saját kiadású vagy vendég folyóiratok megfelelő láthatósága, használhatósága érdekében regisztrálni kell a kiadói archiválási szabályokat a SHERPA RoMEO ${ }^{4}$-ba, minősíttetni a folyóiratot itthon, illetve - a DOAJ által - biztosítani, hogy bekerüljön a hazai közös keresőbe.

4 https://v2.sherpa.ac.uk/romeo/ (utolsó megtekintés: 2021. 09. 23.) 


\section{5.) DOI Azonosítók}

Azon túl, hogy a könyvtárak a repozitóriumaikban elhelyezett és nyilvánossá tett cikkek kiadói DOI-jait rögzítik (és megfelelő beállítások esetén ezáltal láthatóvá teszik az oaDOI adatbázison keresztül), saját maguk is segíthetik a tudományos kommunikációt DOI iroda működtetésével. A kutatási adatokhoz is használt DataCite DOI-knak lehet szerepük a szürke irodalom esetében, de általánosságban a publikációk számára a CrossRef DOI-k több előnyt biztosítanak.

A folyóiratok kiadói ma Magyarországon többnyire már tisztában vannak azzal, hogy a DOI fontos, azt azonban gyakorta nem tudják, mit kell elvégezniük ahhoz, hogy a DOI-k funkciójukat betölthessék.

6.) INTÉZMÉNYI NYÍLT HOZZÁFÉRÉSI POLITIKA KIALAKÍTÁSA ÉS MONITOROZÁSA

Az intézményi nyílt hozzáférés szabályozásának kialakításában is szerepe van a könyvtáraknak - mint végrehajtóknak, monitorozóknak és szakismeretekkel rendelkezőknek. Az intézményi nyílt hozzáférésszabályozás (Open Access Mandate) fontos eleme a gondolkodás és gyakorlat alakításának. A hatékony rendelkezés előír, intézkedik a feltételek megteremtéséről, a kivételekről, az ellenőrzésről és a retorziókról, ill. jutalmazásról. Igen hatékony lehet az a gyakorlat, hogy a teljesítmények elszámolásához csak az intézményi repozitóriumban elhelyezett munkákat veszik figyelembe. Ugyanilyen erős megoldás a CRIS rendszerek (pl. MTMT) alkalmazása, ahol nemcsak a helyi, zöld utas megoldásokat lehet figyelembe venni.

A különböző szabályozásokat listázó szolgáltatások a ROARMAP5 és a SHERPA Juliet ${ }^{6}$.

5 https://roarmap.eprints.org/ (utolsó megtekintés: 2021. 09. 23.)

6 https://v2.sherpa.ac.uk/juliet/ (utolsó megtekintés: 2021. 09. 23.) 
Nemcsak a saját, hanem a finanszírozói és egyéb „külső” OA rendelkezésekről is tájékoztatnia kell a kutatókat a könyvtárosoknak, valamint a kiadói politikákról és az ezek ellenőrzésére használható eszközökről (pl. SHERPA RoMEO) is.

Bekerül a könyvtári feladatok közé az OA statisztikák készítése. Ennek egyik eszközét az MTMT adja.

7.) Folyóiratok ÉS KÖNYVEK előfizetése

Az előfizetési folyamatban - történjen az az EISZ-en keresztül, vagy egyénileg - egyre nagyobb szerepe lesz annak felmérésének, hogy az előfizetendő adatbázisban milyen hányadban szerepelnek szabadon hozzáférhető tartalmak, illetve az előfizetési szerződések tartalmaznak-e OA közlési lehetőséget.

A döntéshozatalban nyújtanak segítséget az EISZ COMPASS és COMPASS+ szolgáltatásai. A COMPASS+ segítségével intézményi OA adat is megállapítható, arra a folyóirat-körre, amit a Dimensions adatbázis lefed. Jelentős könyvtárosi feladat a COMPASS+ adatokkal való feltöltése.

Általában elmondható, hogy a tudományos szakirodalom - a számítás módjától függően, ilyen vagy olyan módon - fele-harmada szabadon hozzáférhető (Holl, 2020c, Archambault et al., 2013). Ezt az arányt két évtized alatt sikerült elérni. Remélhetően a jövőben gyorsabban bővül majd a szabadon elérhető tudományos tartalmak köre. A könyvtáraknak alkalmazkodniuk kell az új realitásokhoz. 


\section{Nyílt kutatási adatok (Open Research Data).}

\section{A TUDOMÁNYOS SZAKKÖNYVTÁRAK ÉS A KUTATÁSI ADATOK KEZELÉSE}

Manapság a nyílt tudomány koncepciója egyre nagyobb figyelmet kap Magyarországon is. A hagyományosabb nyílt hozzáférés mellett ebben megjelenik a kutatási adatok kezelésének témaköre is. Jelen tanulmányunkban azt vizsgáljuk, lehet-e szerepe a tudományos szakkönyvtáraknak a kutatási adatok kezelésében, és ha lehet, mi az.

Először definiáljuk a szabadon hozzáférhetővé tehető kutatási adatok fogalmát! A kutatási adatok - azok a tények, amelyeket a vizsgálatok során felszínre hoznak, kiválogatnak, összegyüjtenek, modelleznek a kutatók - a tudomány nyersanyagai. Míg korábban ezek az adatok naplóbejegyzések formájában, papíron, fénykép, videó vagy hangfelvételekként, összegyüjtött kőzetminták, régészeti leletek, mikroszkópi vizsgálathoz preparált metszetek stb. formájában léteztek, manapság egyre inkább eleve digitális formában születnek, vagy utólagosan digitalizálásra kerülnek. A fejlődő technológia olyan kutatási objektumokról is jó minőségü digitális másolatokat tud készíteni, amelyeket korábban csak kézbe véve, emberi szemmel lehetett megfigyelni. A materiális kutatási adatokhoz lehet ugyan hozzáférést biztosítani, de a kutatási adatokhoz való nyílt hozzáférést csak digitális formában lehet kiteljesíteni. Míg a különböző materiális adatok tárolása, feldolgozása jellegüktől függő (üveglemezre készült fotográfia, kövület, kotta stb.), a digitális adatok tárolása és feldolgozása sokkal hasonlóbb eljárásokat kíván - még ha ezek az eljárások, technikák sokrétúbbek is, mint mondjuk a digitalizált publikációk esetében szükségesek. Mons (2018) definíciója szerint a kutatási adat „egy vagy több digitális objektum együttese, amely a kutatás során keletkezett, vagy a kutatásban felhasználásra kerül".

A könyvtárak nem adattárak; bár az információtechnológiát hamar befogadták, nem rendelkeznek általános szakértelemmel ezen a területen. Nincsen kapacitásuk nagy mennyiségü adat tárolására, a feldolgozást nem is említve. Nem szakértői az adatvizualizációnak, és 
általában nem foglalkoztatnak a különböző tudományterületeken jártas szakembereket (a különféle bölcsészektől eltekintve, akikkel gyakran találkozhatunk a könyvtárosok között). Milyen érv szól amellett, hogy a könyvtárosoknak kutatási adatok kezelésével kellene foglalkozniuk?

Először is, a könyvtárak memória-intézmények, alapfeladatuk, hogy információkat kezeljenek, tegyenek hozzáférhetővé hosszú távon. Lehet, hogy a kutatást végző intézménynek van adattára (fotótára, tervtára, leletraktára stb.) vagy levéltára, de gyakorta a könyvtár az egyetlen megőrző szervezeti egység. Akutatási adatok nem maradhatnak a hosszabb-rövidebb időtávokon létező kutatócsoportoknál, fenntartásukra nem alkalmasak a projektköltségvetések. Sok esetben nem marad más, mint a könyvtár. A könyvtáros-kultúra része a kutatók kiszolgálása, a könyvtárosoknak nagy gyakorlata van a metaadatok terén, használnak (esetenként ki is adnak) állandó azonosítókat, üzemeltetnek, használnak, oktatnak keresőrendszereket.

A kutatási adatok kezelésében három csoportnak is szerepe van: az informatikusoknak, a könyvtárosoknak és a kutatóknak maguknak. De mint intézmény, a könyvtár (vagy Könyvtár és Információs Központ) lehet a megfelelő szervezeti egység. Amennyiben az intézmény elég nagy ahhoz, hogy önálló adattárat működtessen, akkor is gondoskodni kell a könyvtár bekapcsolásáról (az informatikai részleg mellett).

A kutatási adatok jelentős részét nagy projektek (Derek de Solla Pricenál ez a Big Science) hozzák létre. Ezekben az esetekben a költségvetés lehetővé teszi a megfelelő (manapság a FAIR elveket szokás emlegetni) adatkezelést. A nagy projektek adatai specializált adatbázisokba kerülnek. Viszont ott vannak a kis projektek (Little Science), egyedi kutatók, kis csoportok, hagyományosan szerényen finanszírozott területek (pl. bölcsészettudományok) - itt összességében szintén sok kutatási adat keletkezik, és ezek az adatok is értékesek! Ez a kutatási adatok eloszlásának hosszan elhúzódó vége, a „long tail”. Ezeknek az adatoknak a kezelésében különösen fontos szerepe lehet a könyvtáraknak. 
Az egyik ok a szórvány adatok könyvtári kezelésére az, hogy a tárolt információk előhozásának fontos alapelve, hogy az információt valamiféle hálózatban, kontextusban kell elhelyezni. Ilyen hálózat (valójában többszörös hálózat) a bibliográfiai háló. A publikációs csomópontokat a hivatkozások élei kötik össze,-a publikációkat készítő kutatókat pedig társzerzőség alapján lehet összekötni. Az egyes kutatási adatcsomagok is köthetők a rájuk épülő publikációkhoz, az őket létrehozó kutatókhoz, intézményekhez, finanszírozó projektekhez. A tudományos közlemények hálózata alkalmas lehet a kutatási adatok felfedezésére is. A könyvtárak és könyvtári jellegű szervezetek jól kezelik ezeket a hálózatokat.

A fentiek alapján állíthatjuk, hogy a könyvtárak alkalmasak az olyan adatok kezelésére, amelyek szorosan publikációkhoz kapcsolódnak (egy adatsor és az elemzéséből született cikk - de lehetnek bonyolultabb, több cikket vagy több adatsort összekapcsoló relációk is). Olyan adatokat tudnak kezelni, amelyek nem túl nagy terjedelműek, egyszerű (pl. szöveg alapú, mint a CSV, XML, JSON) formátumokban tárolhatók. Nem tudnak kezelni viszont nagy terjedelmü vagy nagyszámú adatállományt, bonyolult formátumokban, amelyek megjelenítése, kezelése speciális szoftvereket igényel. Az adatállományok elhelyezésének eszköze lehet az intézményi repozitórium, ahol az adatok a közlemény mellé helyezhetők. A könyvtárakban történő adatkezelés inkább azokban az esetekben javallott, ahol az adatok szabadon hozzáférhetővé tehetők - a zárt adatkezelés, a speciális jogosítványokat igénylő hozzáférés biztosítása nem a könyvtárakra van szabva.

A kutatási adatok kezelése olyan terület, történjen akármilyen szervezeti egységben is, amelyet csak könyvtárosok, informatikai szakemberek és a kutatók együttműködésével lehet végezni (Holl, 2018b). $\mathrm{Az}$ adatkezeléshez előnyös külön szakembereket alkalmazni; ők az adatgazdászok (data steward). Könyvtári mundérban az egyes kutatási területek adatkezelési gyakorlatához értő könyvtári szakemberek, a kutatói közösségekbe beágyazott könyvtárosok végezhetnek adatgazdászi feladatokat. 
Hatékony könyvtári közreműködés (és általában hatékony kutatási adatkezelés) csak úgy valósítható meg, ha a módszerek, szabványok, technológiák, a munkamegosztás beépül a kutatási ciklusba, illetve ezen belül a kutatási adatok életciklusába.

Többnyire a kutatási adatok kezelésébe való bekapcsolódás azt jelenti a könyvtárak számára, hogy új technológiákat kell bevezetniük. De a könyvtárosok is megtaníthatják a kutatókat és az informatikusokat régi technológiák használatára, jól bevált paradigmák alkalmazására. A könyv (beleértve a digitális médiát, pl. a PDF-et is) könnyen készíthető, olvasható, archiválható. Egy bonyolult adathalmazból is érdemes biztonsági célzattal digitális könyvet készíteni. Sőt, talán még kinyomtatni is érdemes néhány példányban!

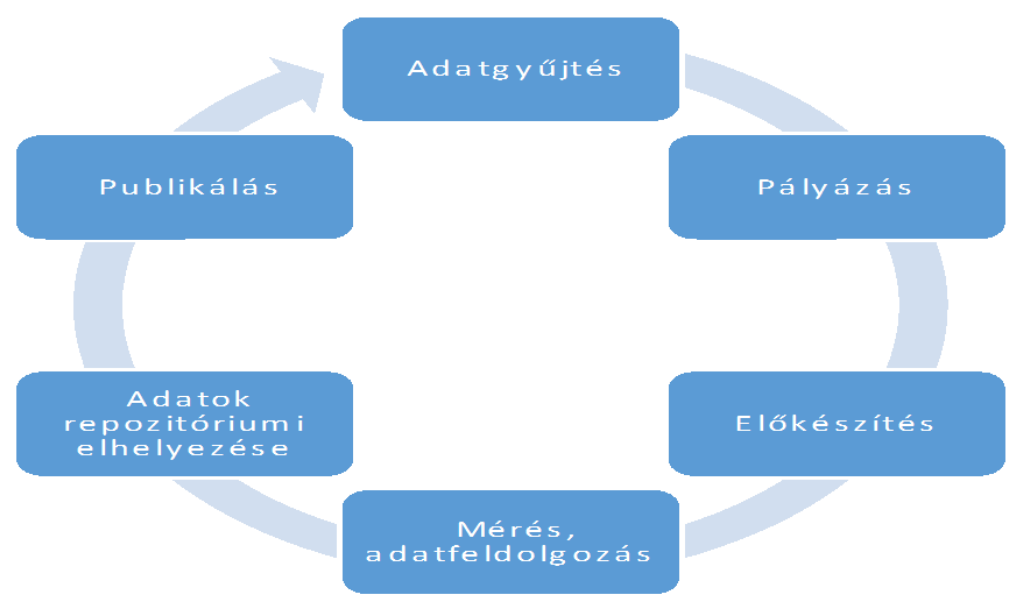

A kutatási adatok kezelési gyakorlatát illetően ajánljuk Mons (2018) könyvét, illetve a könyvtárak lehetséges szerepéről a LIBER által szervezett 2015-ös workshop összefoglalóját ${ }^{7}$, valamint a szervezet

7 https://libereurope.eu/wp-content/uploads/2020/11/LIBER2015_RDM_ workshop_report_2015-1.pdf (utolsó megtekintés: 2021. 09. 23.) 
által megfogalmazott tíz ajánlást ${ }^{8}$. Az egyik első hazai kutatási adatrepozitóriumról Micsik és Gárdos (2014) számol be.

\section{KÖNYVTÁRI SZEREPEK AZ ADATKEZELÉSBEN}

\section{1.) TANÁCSADÁS}

Az olvasószolgálat hagyományos könyvtári szerep. A könyvtárosok az általuk ismert, előfizetett vagy üzemeltetett keresőszolgáltatásokon keresztül (bibliográfiai háló!) segíthetnek a kutatási adatok lokalizálásában, vagy tanácsot adhatnak a láthatóság növelésére.

Magyarországon - de számos más országban is - a könyvtárosok a legaktívabb résztvevők az Open Science mozgalomban. A hazai, kutatási adatkezeléssel foglalkozó rendezvények résztvevőinek többsége könyvtáros (egyfelől szomorú, hogy nem sikerül az ismereteket hatékonyan eljuttatni a kutatókhoz, másfelől viszont rámutat, hol lehet szakértőket találni).

\section{2.) A publikációs Kapcsolat}

Említettük a bibliográfiai hálózatok szerepét. Itt a tudományos szakkönyvtáraknak több feladatuk is lehet.

- Kutatási adatok keresése (l. fentebb). A könyvtárosok segíthetnek a kutatóknak adatokat keresni témakör, kulcsszó, szerző, intézmény alapon, az általuk előfizetett vagy használt kereső rendszerekben (beleértve a discovery service-eket is).

- Tanácsadás a szerzőknek kutatási adatok láthatóbbá tételéhez, a fenti rendszereken keresztül. Itt fontos elem, hogy a kutatási adatok DOI azonosítói legyenek feltüntetve a közleményben, mind a saját

8 https://ibereurope.eu/wp-content/uploads/2020/09/The-research-datagroup-2012-v7-final.pdf (utolsó megtekintés: 2021. 09. 23.) 
adatoké, mind a felhasznált idegen vagy publikus adatoké; megfelelő kulcsszavak elhelyezése.

- A könyvtár által kezelt (pl. repozitóriumban tárolt) kutatási adatok láthatóságának növelése. Itt arról lehet gondoskodni, hogy a könyvtár által biztosított egyablakos kereső (discovery service) arassa a saját adatrepozitóriumot, ill. átvegye a publikációs repozitóriumból az ott tárolt adatállományokra vonatkozó metaadatokat. Ezen túl meg lehet vizsgálni az egyéb, publikációs repozitóriumok felé való, kutatási adatokra vonatkozó adatátadást is (pl. az OIA-PMH kimenet megfelelő konfigurálásával).

\section{3.) Segítség a metaAdatok megadásában}

A kutatási adatok leíró metaadatai (discovery level) azonosak vagy hasonlóak a publikációkéval. Ezek megadásában, kezelésében a könyvtárosoknak nagy tapasztalata van. Ezeknek a metadatoknak a rögzítésére a Dublin Core séma alkalmas. Leíró jellegü adatok származtathatók az adatokhoz tartozó cikk leíró adataiból, jobb híján ezekre támaszkodhatnak a könyvtárosok, illetve ezek az adatok többnyire kiolvashatóak a cikkből is.

A szakmai metaadatok megadása nem könyvtári kompetencia. A könyvtárosok az adott tudományterületen rendelkezésre álló, regisztrált ontológiák, szótárak felderítésében tudnak segíteni, illetve ellenőrizhetik azt, hogy a metaadatok között van-e ilyenekre utalás, és az létező forrásra mutat-e.

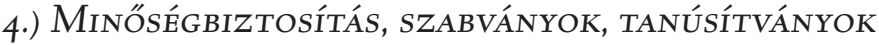

A kutatók - különösen az egyedül, vagy legalábbis nem nagy, nemzetközi együttműködésekben dolgozó kutatók segítségre szorulhatnak abban, hogy adataik megfelelők legyenek a FAIR szempontrendszernek. A tanácsadáson túllépve a könyvtárosok bekapcsolódhatnak az adatmenedzselésbe, a folyamat résztvevőivé válhatnak. Ez lehet a kutatási folyamatba beágyazott könyvtárosí, 
szakterületi adatgazdászi feladat, de történhet abban a fázisban is, amikor a könyvtár által üzemeltetett repozitóriumban elhelyezett adatcsomagok ellenőrzését végzik, a könyvtár által működtetett folyóiratplatform vagy kiadott folyóirat kapcsolt kutatási adatait ellenőrzik, és akkor is, ha a könyvtár szolgáltat DOI azonosítókat az adatok számára.

Az adatokra (és a hozzájuk tartozó metaadatokra) vonatkozó, a FAIR szempontrendszert kibontó elvárásokról az EOSC FAIR WG Metrics and Certificates Task Force anyagaiból, és az anyag által feldolgozott (és hivatkozott) forrásokból lehet többet megtudni. Az EOSC és az RDA különböző munkacsoportjai és projektjei fejlesztenek eszközöket, amelyeket az adatminőség vizsgálatára lehet használni.

$\mathrm{Az}$ adatminőség ellenőrzésének véleményünk szerint a legfontosabb eszköze a szakterületről kikerülő lektor/bíráló véleménye, a peer review. Az ideális folyamat az, hogy ha a közlésre benyújtott cikket bíráló független szakértőkhöz eljutnak azok az adatok is, amelyekre a kutatás alapul. Ez a cikk bírálata szempontjából is előnyös, és az adatokéból is. A cikk gyakorta a legjobb leírást nyújtja az adatokról, a kutatás motivációjától az adatok részletes, a keletkezés (megfigyelés, kísérlet, szimuláció) körülményeinek leírásán keresztül a minőség megítéléséig minden szempontból.

Ha a kutatók tanácsért fordulnak a könyvtárhoz, az elhelyezésre ajánlott repozitóriumoknál szempont a minőségi tanúsítványok megléte. De ennél is fontosabb, hogy a könyvtár által működtetett repozitóriumok, kiadott folyóiratok tanúsítvánnyal rendelkezzenek. Ezeken a területeken lehetséges hazai, az MTMT Repozitóriumminősítő bizottságával minősíttetni a repozitóriumot. A minősítés általában idő (és néha anyagi) befektetést igényel. A hazai rendszer követelményei általában valamivel alacsonyabbak a nemzetközieknél, a hazai minősítésre lehet a nemzetközi minősítés előszobájaként tekinteni. Open Access folyóiratoknál a nemzetközi minősítés a DOAJ által történhet, repozitóriumoknál a még reálisan megszerezhető tanúsítvány a CoreTrustSeal. 


\section{5.) Technikai KéRdések}

Ez az a terület, ahol a könyvtárak legkevésbé járatosak. Formátumok, tömörítés/csomagolás, az adatok változatlanságát biztosító eszközök (checksum, CRC stb.), tárhely, jogosítványok, megjelenítés, feldolgozás - mind-mind fontos, a könyvtárak által nehezen kezelhető kérdések. Ajánlatos a könyvtáraknak olyan „gyüjtőkört” kialakítani, ahol ezek a legkevésbé jelentenek akadályt. Nem tartozik a könyvtárak kompetenciájába az adatok feldolgozása sem - az igen nagy adattömegeknél nem az adatokat kell elvinni a feldolgozás helyére, hanem a felhasználó algoritmusait, programjait kell az archívumban lefuttatni.

Jó példa (az MTA KIK gyakorlatából), amikor egy pszichológus kért segítséget adatai elhelyezéséhez, ami nélkül nem közölte volna a cikkét egy nemzetközi folyóirat. A publikációs repozitóriumba kerültek a CSV formátumban lévő adatok (kérdőívek kiértékelése), a cikk valamilyen változata mellé. Néhány kisméretű fájl, szöveges formátum, melynek megjelenítéséhez nem kell külön szoftver, amely bizonyos mértékig ellenőrizhető „ránézéssel”. Az adatok felderíthetőségét a cikk felderíthetősége biztosítja.

Ha a könyvtárak ennél bonyolultabb feladatra vállalkoznak, fontos, hogy megfelelő (szabványos, elterjedt, nyílt, szabad szoftverrel olvasható és írható) formátumokat követeljenek meg, és a metaadatok között biztosítsák a technikai információk elhelyezését: pl. formátum (verzió), szükséges szoftverek felsorolása, méret, fájlok száma, ellenőrző összegek.

\section{6.) JoGI KÉRDÉSEK, FELHASZNÁLÁSI LICENC}

Szükséges az adatok elhelyezőjét nyilatkoztatni arról, hogy az adatok elhelyezésének, nyilvánosságra hozatalának nincs akadálya, nem merülnek fel etikai vagy személyiségi jogi problémák. 
Ugyancsak fontos kritérium a megfelelő felhasználási licenc alkalmazása. Ez lehet az elterjedt Creative Commons licenc-család valamelyik tagja, szoftvereknél valamilyen elterjedt szoftverlicenc (GNU, Apache stb.).

\section{7.) SZÜRKE IRODALOM}

Ez az egyik terület, ahol a könyvtárak szerepe a leghatározottabb lehet. A kutatási adatok (illetve az egész kutatási folyamat) megfelelő, a reprodukálhatóságot vagy újra-felhasználhatóságot biztosító dokumentálásához szükség lehet a felhasznált műszerek, szoftverek, módszerek, de akár az egész laboratórium, obszervatórium dokumentálására. A publikációk esetében elvárás ugyan, hogy ezekre legyen valamilyen utalás, de a publikációk terjedelmi korlátai miatt ez gyakorta nem lehet a reprodukáláshoz, ellenőrzéshez elegendően részletes.

A könyvtárak fontos szerepe a fent említett részletes dokumentációk ez könyvtári zsargonban a szürke irodalom - tárolása, hozzáférhetővé és hivatkozhatóvá tétele.

\section{8.) Egyedi AZONOSÍTók}

Kulcsfontosságú az egyedi, állandó azonosítók használata. Manapság a leginkább népszerű a DOI, illetve az ORCID. Az előbbi alkalmas mind publikációk, mind a szürke irodalom, mind a kutatási adatcsomagok vagy rekordok azonosítására, az utóbbi szerzőazonosító. A kutatási folyamatban nagy igény van a résztvevő intézmények, illetve a kutatáshoz felhasznált pályázati támogatások azonosítására is. Ilyen azonosítási lehetőségeket kínál rendre a GRID és a Funder Registry. $\mathrm{Az}$ adatokat használó cikkek DOI-jait el kell helyezni az adatok leíró metaadataiban. Ideális esetben az adatok újrafelhasználásával foglalkozó cikkekre való hivatkozásokkal (és azok DOI-jaival) is lehet bővíteni utólagosan a metaadatokat. 
Míg a többi azonosítót a metaadatok gazdagítására kell használni, magának az adatállománynak DOI-t kell adni. Erre a célra a DataCite DOI alkalmas. Fontos kérdés a granularitás: egy nagy csomagba kell minden adatot összevonni, és annak DOI-t adni, vagy logikus részenként, esetleg minden egyes részadatnak szüksége van DOI-ra? Sajnos, a granularitás kezelése a DOI definícióban és a feloldási mechanizmusokban nem szerepel, ezt öntevékenyen kell kialakítani. Mindazonáltal a könyvtári gyakorlatban kevés DOI kiadását, egyszerű sémákat kell előnyben részesíteni.

A nagyszámú DOI hozzárendelése manuálisan amúgy sem kivihető - itt már automatizmusokra van szükség, amit esetleg az adatrepozitóriumszoftverek vagy adatbázis-szoftverek lehetnek képesek a DataCite rendszerén keresztül regisztrálni.

Újrafelhasznált adatok esetében akkor logikus új DOI-k regisztrálása, ha az adatállományt nem egészében használják (pl. egy dinamikus adatbázisból egy SQL lekérdezés eredményét). Ilyenkor a lekérdezéssel kapott adatokat célszerű archiválni, és új DOI-val ellátni. Persze a metaadatokban hivatkozni kell az eredeti adatbázis DOI-jára, amennyiben van ilyen.

\section{9.) Az aDATOK FAIR MiVOLTA NEM ANNYiRa ÁLLAPOT, MINT FOLYAMAT (FAIR IS A JOURNEY)}

Egy adatcsomag ritkán képes minden előírásnak megfelelni - már csupán azért sem, mert az évek során maguk az elvárások is változnak. Ez részben azt jelenti, hogy a hiányosan dokumentált, nem minden szempontnak megfelelő adatközlés is jobb, mintha az adatok a fiókban maradnának. Másrészt az adatok elhelyezése, leírása lehet egy iteratív folyamat. Beleértve azt is, hogy hosszú távon szükség lehet az adatok más formátumba való migrálására, a metaadatok kiegészítésére, az adatokkal kapcsolatban az elhelyezés óta történt fejlemények dokumentálására. A hazai könyvtárakban, attól tartunk, nemigen vannak erőforrások erre - ezért is fontos az előrelátó gondoskodás (lásd fentebb). 
Valamelyes utógondozásra, persze, van lehetőség - a publikációs repozitóriumok esetében is megszokhatták már a könyvtárosok az újabb, javított verziókra vagy javított metaadatokra vonatkozó szerzői vagy olvasói kéréseket. A nyílt hozzáférés minőségbiztosítási szempontból is fontos: amilyen hibát, problémát a könyvtárosok nem vesznek észre, azt az olvasók (felhasználók) észrevehetik.

\section{0.) SZABÁLYOZÁSOK, ADATKEZELÉSI TERVEK}

A nyílt hozzáféréshez hasonlóan a könyvtáraknak szerepük lehet a kutatási adatok kezelésére vonatkozó szabályozások kialakításában ha ez a szerep csekélyebb is. Nem csupán az illetékesség, tapasztalat kisebb, de ezen a területen a szabályozások sem lehetnek olyan részletesek, olyan egyértelműek. Nagyon változatos az egyes területek, sőt, azon belül az egyes projektek adatkezelése. Csak nagy vonalakban vagy áttételesen lehet szabályozni. Kevesebb a külföldi példa is, amire támaszkodni lehetne.

Az egyik lehetőség - ez már Magyarországon is megvalósul az OTKA pályázatoknál - az adatkezelési tervek megkövetelése. Az adatkezelési tervek elkészítésének támogatása viszont fontos könyvtári szerep.

\section{1.) A kutatási adatok Nyilvántartása}

A nyilvántartás egyik formája a projektbeszámoló - ez a finanszírozó számára jelzi az adatkezelési terv megvalósulását. Fontos azonban, hogy az intézményi és kutatói teljesítmény-nyilvántartásba is bekerüljenek a nyilvánosságra hozott kutatási adatok, a szerzőség, intézményi affiliáció és a felhasznált pályázati támogatás összekapcsolásával. Magyarországon az MTMT lehetőséget ad kutatási adatok rögzítésére.

Lehetőség van - a publikációkhoz hasonlóan - a közzétett kutatási adatok hatásának mérésére is, az idézéseken keresztül. A közleményekhez felhasznált, más projektek által létrehozott és közzétett adatokra természetesen hivatkozni kell, méghozzá DOI-val. Ezek a hivatkozások 
az indexelt folyóiratokból bekerülnek a Clarivate Data Citation Index-ébe. Az MTMT is rögzíteni tudja a nyilvántartott adatokra érkezett hivatkozásokat. A könyvtárosok részt vehetnek a hivatkozások gyüjtésében.

\section{2.) Publikus kutatási adatok keresése}

Mint ahogy a szakirodalom összegyüjtése az egyik első lépése egy kutatási projektnek, a tervezett vizsgálathoz kapcsolódó korábbi kutatások adatainak felderítése is meg kell előzze a saját adatgyüjtést. Mi az, ami már létezik, hozzáférhető, így nem kell összegyüjteni, megmérni, megfigyelni, modellezni? A felvetett kérdést meg lehet-e válaszolni már létező adatok alapján? Vannak-e olyan publikus adatok, amelyek kiegészíthetik az új projekt során keletkezőket?

A hatékony adatkeresés a szakirodalmi kereséssel rokonítható. A könyvtárosoknak meg kell ismerniük az általános adat-aggregátorokat (mint az EOSC, a csillagászatban az Astrophysics Data System) és adatbankokat, fel kell készülniük, hogy esetleg segíteniük kell a kutatóknak az adatokhoz való hozzáférésben.

Túl a kifejezetten adatkeresésre készült szolgáltatásokon a szakirodalmi keresés is szolgáltathat eredményeket. A NASA/SAO ADS csillagászati bibliográfiai adatbázis biztosít olyan keresési lehetőséget, amellyel felderíthető, hogy milyen adatbázis tartalmaz egy adott cikkhez társítható adatokat. (Elképzelhető egy olyan keresés, amelyben egy szerzőnévhez vagy objektum-azonosítóhoz kapcsolódó, bizonyos archívumban tárolt adatok léte felderíthető.) Ez előrevetíti, hogy bibliográfiai/könyvtári adatbázisokban, könyvtárosi tudással lehet kutatási adatokat felderíteni.

\section{3.) MunkafolyamatoK KialakítÁsa a KUTATÁsi adatoK KeZelÉSÉBEN}

Vitathatatlan, hogy a kutatási adatok megfelelő kezelése - tervezés, dokumentálás, ellenőrzés, egyedi azonosítók biztosítása s minden, ami 
szükséges lehet - jelentős terheket jelent. Természetesen a befektetett munka a későbbiekben - a kutatási eredmények verifikálásánál, újrafelhasználásánál - jelentős könnyebbséget, megtakarítást eredményezhet. Mindazonáltal nehéz a megfelelő adatkezelési gyakorlatot biztosítani. Minél inkább sikerül az adatkezelési szempontokat a munkafolyamatokba beépíteni és automatizálni, annál könnyebb lesz a megvalósítás (Holl, 2020a). A könyvtárosok segítséget nyújthatnak a munkafolyamatok megtervezésében is.

Van példa arra is, hogy az intézményi könyvtárak közreműködtek egy virtuális kutatási munkakörnyezet kialakításában (Sennyey és Kokas, 2020).

A kutatási adatok kezelésével kapcsolatos technológiák és szabványok kifejlesztésére és támogatására jött létre az Research Data Alliance (RDA); ennekhazai szervezete a HRDA.Érdemes a hazai fejlesztésekben és gyakorlatban az RDA szabványaira és a HRDA honosított anyagaira és szakértelmére támaszkodni. 


\section{Nyílt FORRÁSKÓDÚ, SZABAD KUTATÁSI SZOFTVEREK}

A nyílt forráskódú, szabad szoftverek hosszú múltra tekintenek vissza. Az 1970-es évek végéről a TeX szövegszedő rendszer (Donald Knuth), az 1980-as évek elejéről a GNU projekt (Richard Stallman), valamint az 1990 -es évek elejéről a Linux (Linus Torvalds) ismert példák.

A nyílt forráskódú szoftverek felhasználási jogainak rögzítésére számos jogi lehetőség áll rendelkezésre, mint a GNU GPL, az Apache, a BSD vagy a MIT licencek.

A szabad forráskód alkalmazását támogató projekt az Open Source Initiative ${ }^{9}$. Több tudományos folyóiratot is kiadnak a nyílt forráskód témája területén, mint a The Open Source Software ${ }^{10}$ és a Journal of Open Research Software (JORS) ${ }^{11}$.

Ugyancsak számos szoftver forráskód lista és tár (repozitórium) áll a fejlesztők rendelkezésére, előbbire példa a SourceForge ${ }^{12}$, utóbbira a GitHub $^{13}$. A kód repozitóriumok sok tekintetben különböznek az előző részekben tárgyalt repozitóriumoktól - lényeges, hogy funkcióikkal támogatják a csoportmunkát, és nem csupán a kódok referenciaként való archiválása, de változásaik nyomon követése is hangsúlyos.

Ajánljuk az Open Science MOOC ${ }^{14}$ oldalt, amelyen számos további információ található.

9 https://opensource.org/ (utolsó megtekintés: 2021. 09. 23.)

10 https://joss.theoj.org/(utolsó megtekintés: 2021. 09. 23.)

11 https://openresearchsoftware.metajnl.com/ (utolsó megtekintés: 2021. 09. 23.)

12 https://sourceforge.net/ (utolsó megtekintés: 2021. 09. 23.)

13 https://github.com/ (utolsó megtekintés: 2021. 09. 23.)

14 https://opensciencemooc.eu/ (utolsó megtekintés: 2021. 09. 23.) 


\section{Nyílt FORRÁSKóDÚ SZOFTVEREK ÉS A KÖNYVTÁRAK}

Ha jelenleg nem is elterjedt, de a jövőben elképzelhető, hogy a szakkönyvtáraknak szerepük lesz a nyílt forráskódú szoftverek területén is.

\section{1.) DOI Azonosítók}

A szoftverekre való hivatkozás lehetôségét is DOI-val lehet elérni. A GitHub útmutatójában a DOI-t a CERN Zenodo archívumában való archiválással javasolják beszerezni ${ }^{15}$.

\section{2.) HivatKozÁs NYílt FORRÁSKódú SZOFTVEREKRE}

Fontos, hogy a publikációk hivatkozzanak a felhasznált szoftverekre, lehetőleg DOI-val. Hivatkozási lehetőséget teremt, ha a szoftverről publikáció jelenik meg - erre alkalmas folyóirat például a JORS. De elképzelhető a szürke irodalomban való publikálás is - itt a szoftvert leíró cikket el lehet helyezni az intézményi repozitóriumban.

\section{3.) Metaadatok}

Érdemes a JORS cikkeit megnézni, milyen speciális metaadatokat kell megadni az általános DC leíró metaadatokon (pl. cím, szerzők, dátum, nyelv) túl:

- operációs rendszer;

- programozási nyelv;

- függőségek;

- kód repozitórium, projektnév;

- licenc.

15 https://guides.github.com/activities/citable-code/ (utolsó megtekintés: 2021. 09. 23.) 
A kutatásban használatos szoftverek FAIR tulajdonságaival foglalkozó RDA csoportok:

- FAIR4RS ${ }^{16}$;

- Software Source Code IG ${ }^{17}$.

4.) NyÍlt FORRÁSKÓDÚ SZOFTVEREK A KÖNYVTÁRAKBAN

Bár tárgykörünkön kívül esik ez a téma, meg kell említsük, hogy az integrált könyvtári rendszerek és platformok között is vannak nyílt forráskódúak - pl. a KOHA ${ }^{18}$.

Jelentős nyílt forráskódú könyvtári kezdeményezés a FOLIO ${ }^{19}$, ami az OSZK Országos Könyvtári Platform projektjének alapjául is szolgál (Lendvay, 2020).

\section{NYÍlt OKTATÁSI ERŐFORRÁSOK - OPEN EdUCATIONAL RESOURCES}

A nyílt oktatási lehetőségeket (Open Educational Resources) nem mindenki sorolja a nyílt tudomány körébe - de mivel a képzés a kutatás elválaszthatatlan része, és mivel az egyetemi könyvtáraknak e téren is feladatai vannak, mi foglalkozunk vele. A terület egyik úttörője az $\mathrm{MIT}^{20}$.

Az egyik legjelentősebb, hazánkban is elterjedt platform a MOOC (Massive Open Online Course).

16 https://www.rd-alliance.org/groups/fair-research-software-fair4rs-wg (utolsó megtekintés: 2021. 09. 23.)

17 https://www.rd-alliance.org/groups/software-source-code-ig (utolsó megtekintés: 2021. 09. 23.)

18 https://libereurope.eu/article/going-open-source-koha-in-an-academiclibrary/ (utolsó megtekintés: 2021. 09. 23.)

19 Future of Libraries is Open https://www.folio.org/ (utolsó megtekintés: 2021. 09. 23.)

20 https://ocw.mit.edu/ (utolsó megtekintés: 2021. 09. 23.) 
A könyvtárak szerepét az elektronikus tananyagok archiválásában Nagy (2018) tárgyalja, a hazai MOOC platformokat pedig Tarcsi (2019) szemlézi.

Könyvtári információs anyagok: IFLA ${ }^{21}$, SPARC Europe ${ }^{22}$.

\section{Nyílt tudományos bírálat (Open Peer Review)}

Új és gyorsan fejlődő terület, a tudományos publikációk bírálatának új paradigmája. Leírását lásd Ross-Hellauer (2017) cikkében, Görögh et al. (2017) projektjelentésében valamint a PLOS $^{23}$ és a FOSTER ${ }^{24}$ weboldalain.

A nyílt tudományos bírálat alapvető szempontjai:

- nyílt részvétel: a szerzők és a bírálók neve nyilvános;

- nyílt bírálatok (a bírálat nyilvánosan elérhető a publikáció mellett);

- nyílt együttműködés (párbeszéd a résztvevők között);

- nyílt részvétel (nem csupán a felkért bírálók vehetnek részt a bírálati folyamatban

- nyílt platform (a kiadóktól független platform);

- nyílt kéziratok (a beküldés után rögtön láthatók)

- nyílt megjegyzések utólagos hozzáfüzésének lehetősége.

Mind a nyílt tudományos bírálatot bevezető folyóiratok és kiadók (pl. az Atmospheric Chemistry and Physics, PeerJ, F1000Research), mind a kiadóktól független platformok (pl. PubPeer ${ }^{25}$, Publons $^{26}$ ) mind

21 https://www.ifla.org/files/assets/clm/news/oer_ifla_brief.pdf (utolsó megtekintés: 2021. 09. 23.)

22 https://sparceurope.org/open-education-in-european-libraries-of-highereducation-initial-results/ (utolsó megtekintés: 2021. 09. 23.)

23 https://plos.org/resource/open-peer-review/ (utolsó megtekintés: 2021. 09. 23.)

24 https://www.fosteropenscience.eu/learning/open-peer-review/\#/ id/5a17el50c2af65ldle3blbce (utolsó megtekintés: 2021. 09. 23.)

25 https://pubpeer.com/ (utolsó megtekintés: 2021. 09. 23.)

26 https://publons.com/about/home/ (utolsó megtekintés: 2021. 09. 23.) 
az úgynevezett „overlay journal”-ek (repozitóriumokban elhelyezett kéziratokat válogató folyóiratok, pl. az Open Journal of Astrophysics) fontosak a megvalósításban. Ez utóbbiakról lásd Gibney (2016).

A könyvtáraknak egyfelől tájékoztatási feladatuk lehet, másfelől a könyvtárak által működtetett vagy használt kutatásértékeléshez használatos adatbázisokban (MTMT, CRIS rendszerek) előbb-utóbb meg fognak jelenni az egyes kutatók bírálati tevékenységének mutatói. A repozitóriumokban archivált cikkek mellé pedig bekerülhetnek a bírálatok. (A REAL-d-ben 2010 óta archivált MTA doktori dolgozatok mellett már megtalálhatóak a bírálatok is.)

Könyvtári tájékoztatók a nyílt tudományos bírálatról: ACRL 27, OU²8.

\section{Közösségi tudomány (Citizen Science)}

A közösségi tudománnyal részletesebben kötetünk külön fejezete foglalkozik. Itt néhány platformot ismertetünk.

$\mathrm{Az}$ Európai Unió EU-CITIZEN.SCIENCE projektje ${ }^{29}$ lehetséges kezdőpont a tájékozódáshoz. Az Egyesült Államokban hasonló gyüjtőoldal a citizenscience.gov ${ }^{30}$. Közösségi tudományos projektek webes felületeinek kialakítását támogató platformok:

- Ecsite - EU Cítizen Science platform ${ }^{31}$

- Zooniverse.

27 http://www.ala.org/acrl/publications/keeping_up_with/opr (utolsó megtekintés: 2021. 09. 23.)

28 https://libraries.ou.edu/content/establish-your-expertise-open-peer-review (utolsó megtekintés: 2021. 09. 23.)

29 https://eu-citizen.science/ (utolsó megtekintés: 2021. 09. 23.)

30 https://www.citizenscience.gov/ (utolsó megtekintés: 2021. 09. 23.)

31 https://www.ecsite.eu/activities-and-services/projects (utolsó megtekintés: 2021. 09. 23.) 


\section{Nyílt kutatási JegyzőKönYvek (Open Lab Notebooks)}

A kísérleteket, a kutatási munkafolyamatokat egyre inkább automatizálni lehet. Az amúgy is gépesített, informatikai környezetben megvalósuló, vagy legalábbis informatikai eszközökkel irányítható munkafolyamat lekódolható, és eltárolva újrafuttatható (szükség esetén változtatásokkal). A munkafolyamat-automatizálás jelentősen megkönnyíti a kutatást, különböző eljárások és paraméterek próbálhatók végig rövid idő alatt. Maga a megfigyelés, a kísérlet is megismételhető lehet esetenként, de a szimuláció, az adatfeldolgozás, a vizualizáció, a publikáció technikai elkészítése mindenképp.

A terület áttekintését Schapira et al. (2019) cikkében találhatjuk.

A legelterjedtebben használt szoftver a JupyterNotebooks ${ }^{32}$.

A hagyományos (szöveges) kísérleti megosztására szolgáló platform az openlabnotebooks ${ }^{33}$.

32 https://jupyter.org/ (utolsó megtekintés: 2021. 09. 23.)

33 https://openlabnotebooks.org/ (utolsó megtekintés: 2021. 09. 23.) 


\section{Appendix}

\section{OAI-PMH - Protocol for Metadata Harvesting}

Az Open Archives Initiative által kidolgozott metadatat-aggregációs protokolli34. Magyar nyelvü leírás a SZTAKI és a MEK HEKTÁR projektje keretében készültt ${ }^{35}$.

A protokollt támogatják a különböző, nyílt forráskódú és szabad repozitórium-szoftverek, mint az EPrints, a DSpace és Dataverse, és a hasonlóan szabad Open Journal Systems folyóiratmenedzselő és publikációs platform. Aggregátor oldalon használja a magyar OAI közös kereső"36, a DART-Europe európai e-disszertációs portál37, a Jisc CORE ${ }^{38}$, a Bielefeld Academic Search Engine (BASE) ${ }^{39}$, a szegedi CONTENTA repozitóriumok közös keresője (Farkas és Sándor, 2020) és a PRIMO, hogy csak példákat soroljunk.

\section{SWORD}

Az Atom Publishing Protocol-ra épülő teljes szövegű tartalmak és metaadataik cseréjét lehetővé tevő egyszerű protokoll (Simple Web-service Offering Repository Deposit) ${ }^{40}$. Alapvető fontosságú a különböző digitális szolgáltatások között magvalósított adatcsere automatizálásában.

Ezt a protokollt használja a repozitóriumi feltöltés MTMT-ből való kezdeményezését lehetővé tevő szolgáltatás. A protokollt támogatják az elterjedt, szabad forráskódú, ingyenes repozitórium-szoftverek, mint az EPrints és a DSpace. Az MTMT-ben való alkalmazását megelőző kísérletekről l. Holl et al. (2009).

34 https://www.openarchives.org/pmh/ (utolsó megtekintés: 2021. 09. 23.)

35 http://hektar.sztaki.hu/oai.html (utolsó megtekintés: 2021. 09. 23.)

36 http://oaikereso.sztaki.hu/ (utolsó megtekintés: 2021. 09. 23.)

37 https://www.dart-europe.org/ (utolsó megtekintés: 2021. 09. 23.)

38 https://core.ac.uk/ (utolsó megtekintés: 2021. 09. 23.)

39 https://www.base-search.net/ (utolsó megtekintés: 2021. 09. 23.)

40 http://swordapp.org/ (utolsó megtekintés: 2021. 09. 23.) 


\section{REPOZITÓRIUM}

A repozitóriumok olyan digitális könyvtári szolgáltatások, amelyek az Open Archives Initiative nyomán jöttek létre. Nem minden weben elérhető digitális tartalomgyüjteményt lehet így nevezni - a repozitóriumok lényegi tulajdonságai a következők (a korábbiakban az elvárásokat inkább technikai szempontból soroltuk fel):

- nyílt hozzáférés biztosítása (a tartalmak többségéhez);

- teljes szövegü tartalmak szolgáltatása;

- aggregálhatóság;

- hosszú távú (vagy legalábbis évtizedekre való) hozzáférés biztosítása;

- minőségbiztosítás (könyvtárosi ellenőrzés).

Ezen felül a repozitóriumok többnyire megfelelnek az alábbi kritériumoknak is:

- kutatói önfeltöltés lehetősége;

- a szolgáltatások közötti tartalomcserét támogató mechanizmus;

- hozzáférési korlátozások alkalmazásának lehetősége.

A hazai repozitóriumokat üzemeltető közösség szakmai szervezete a HUNOR ${ }^{41}$. Hazai minősítő szervezet az MTMT Repozitóriumminősítő Bizottsága ${ }^{42}$.

A repozitóriumok megújítására, szolgáltatásaik bővítésére nagy igény mutatkozik (Holl, 2018c). Fejlesztésre kényszeríthetnek egyes repozitóriumokat az EU vagy a Plan S követelményei ${ }^{43}$.

41 https://openscience.hu/hunor/ (utolsó megtekintés: 2021. 09. 23.)

42 https://www.mtmt.hu/repozitoriumminosito-szakbizottsag (utolsó megtekintés: 2021. 09. 23.)

43 https://www.coalition-s.org/plan-s-practical-advice/ (utolsó megtekintés: 2021. 09. 23.) 


\section{DOI - Digital Object Identifier}

Állandó, egyedi azonosító digitális formában (is) létező objektumok számára. A Handle technológián alapul ${ }^{44}$. A DOI rendszer mögött az International DOI Foundation áll ${ }^{45}$.

A DOI azonosítók kiadása DOI ügynökségeken keresztül történik, ilyen a CrossRef ${ }^{46}$ és a DataCite ${ }^{47}$.

A DOI előnyei:

- a dokumentum elérési helyének változása esetén sem változó link megadása (ehhez az kell, hogy a dokumentum helyének megváltozását követően az adatgazda az új URL-t átvezesse a DOI adatbázisba (ezt a Handle rendszer biztosítja);

- kereshetőség a DOI adatbázisban rögzített adatok alapján (ehhez, persze, elegendő adatot meg kell adni);

- hivatkozások nyilvántarthatósága (pl. a CrossRef Cited-by szolgáltatásának használatával);

- láthatóság növekedést eredményez (CrossRef - a hivatkozó cikkeket olvasók kattintásain keresztül);

- a kutatásfinanszírozók és a CRIS rendszerek (MTMT-t is beleértve) számára jobb lehetőségeket kínál a kutatási termékek nyilvántartására.

A DOI azonosítók általában pénzbe kerülnek. A CrossRef szabályai szerkesztőségi vagy szerzői többletmunkára köteleznek (irodalomjegyzékben DOI linkek elhelyezése).

Az MTA KIK DOI regisztrációs szolgáltatásairól a weben lehet tájékozódni ${ }^{48}$.

44 https://www.handle.net// (utolsó megtekintés: 2021. 09. 23.)

45 https://www.doi.org/index.html (utolsó megtekintés: 2021. 09. 23.)

46 https://www.crossref.org/ (utolsó megtekintés: 2021. 09. 23.)

47 https://datacite.org/ (utolsó megtekintés: 2021. 09. 23.)

48 https://openaccess.mtak.hu/index.php/kiadoknak/doi (utolsó megtekintés: 2021. 09. 23.) 


\section{ORCID - Open Researcher and Contributor ID}

Szerzőazonosító rendszer, az ISNI-vel megegyező technológiával, annak részeként ${ }^{49}$. Az azonosítóról bővebben lásd Holl és Bilicsi (2017) cikkét. Az ORCID azonosító megadását számos folyóirat megköveteli, és számos szoftver támogatja. Az MTMT biztosítja az ORCID azonosító hiteles bevitelét, és az ORCID-on keresztül való bejelentkezést is.

Csak akkor van értelme az azonosító használatának, ha a kutató az ORCID profiljában megad különböző adatokat (mind végzettségről, mind a munkahelyeiről, mind a legfontosabb publikációit).

\section{FAIR - Findable, Accessible, Interoperable, Reusable}

A nyílt tudomány (Open Science) mozgalom eredeti célkitűzései szerint a tudományos közlemények szabad hozzáférhetőségéhez hasonlóan a kutatási adatok is szabadon hozzáférhetővé kell váljanak. Mivel ez sok esetben akadályokba ütközik, paradigmaváltás történt: „a kutatási adatok legyenek annyira nyíltak, amennyire lehetséges, és annyira zártak, amennyire szükséges” („As open as possible, as closed as necessary”). A kutatási eredmények ellenőrzéséhez szükséges az adatok rendelkezésre állása és a jó dokumentáció. Újrafelhasználásukhoz pedig megtalálhatónak, szabványosnak kell lenniük, és nyilvánvalóak kell legyenek a felhasználás feltételei.

A FAIR betűszó a következőképp oldható fel: Findable, Accessible, Interoperable, Reusable (megtalálható, hozzáférhető, szabványos, újrafelhasználható).

2016-ban jelentek meg a FAIR alapelvek (Wilkinson, 2016). Az alapelvek leírása megtalálható a FORCEll és a GoFAIR honlapjain ${ }^{50}$.

49 https://orcid.org (utolsó megtekintés: 2021. 09. 23.)

50 https://www.forcell.org/group/fairgroup/fairprinciples; https://www.go-fair.org/fair-principles (utolsó megtekintés: 2021. 09. 23.) 
A betűszóban összegzett alapelvek lényege tömören a következő:

F: Findable (megtalálható)

- Egyedi azonosítóval rendelkezik (pl. DOI);

- gazdagon el van látva leíró adatokkal (metaadatok);

- be van jegyezve, indexálva van valamilyen nyilvános, kereshető szolgáltatásba.

\section{A: Accessible (hozzáférhető)}

- Az egyedi azonosítón keresztül mind a leíró adatok, mind maguk az adatok elérhetőek valamilyen szabványos protokoll segítségével;

- a protokoll nyílt, ingyenes, elterjedt;

- a protokoll lehetővé teszi az azonosítást és a jogosultság-kezelést, amennyiben erre szükség van;

- a leíró adatok akkor is hozzáférhetőek, ha az adatok már nem.

I: Interoperable (szabványos)

- Az adatok és a leíró adatok szabványos és értelmezhető formában vannak;

- a leíráshoz, adatrögzítéshez, dokumentációhoz használt szótárak maguk is eleget tesznek a FAIR alapelveknek;

- sok kereszthivatkozás segíti az értelmezést.

R: Reusable (újra-felhasználható)

- Egyértelmű felhasználási licenc áll rendelkezésre;

- az adatok származása, keletkezése jól dokumentált;

- megfelel a tudományterületi szabványoknak.

A gyakorlatban alkalmazható FAIR kritériumokról bővebb információ található az EOSC FAIR WG Metrics and Certification TF anyagaiban, amelyek hivatkoznak a különböző releváns projektek dokumentumaira is. 


\section{CRIS - Current Research Information System}

A kutatásirányítást támogató komplex információs rendszer. Adatbázisaiban információk találhatók a kutatókról, a publikációkról, a projektekről, a kutatási infrastruktúrákról. Működhet intézményi, de országos szinten is. Magyarországon nincs integrált országos CRIS rendszer, de az MTMT betölti a publikációs nyilvántartó szerepét. Nemzetközi, CRIS támogató szervezet az euroCRIS ${ }^{51}$. A CRIS információk szabványa a Common European Research Information Format (CERIF) ${ }^{52}$.

Léteznek kommerciális CRIS szoftverek, mi itt a szabad forráskódú, Dspace alapú Dspace-SRIS-t említjük meg ${ }^{53}$.

\section{EOSC - European Open Science Cloud}

Európai kezdeményezés egy FAIR alapokon működő, különböző szolgáltatásokat integráló felhő és portál kialakítására ${ }^{54}$.

\section{RDA - Research Data Alliance}

A kutatási adatkezelés technikái és szabványai kidolgozására és támogatására létrejött szervezet, egyéni tagsággal ${ }^{55}$. Magyar tagszervezete a HRDA ${ }^{56}$.

51 https://eurocris.org/ (utolsó megtekintés: 2021. 09. 23.)

52 https://eurocris.org/services/main-features-cerif (utolsó megtekintés: 2021. 09. 23.)

53 https://wiki.lyrasis.org/display/DSPACECRIS/DSpace-CRIS+Home (utolsó megtekintés: 2021. 09. 23.)

54 https://ec.europa.eu/info/research-and-innovation/strategy/goals-research-andinnovation-policy/open-science/eosc_en (utolsó megtekintés: 2021. 09. 23.)

55 https://www.rd-alliance.org/ (utolsó megtekintés: 2021. 09. 23.)

56 http://hrda.hu/ (utolsó megtekintés: 2021. 09. 23.) 


\section{HUNOR - Hungarian Open Access Repositories}

A hazai (egyelőre inkább publikációs) repozitórium-üzemeltető intézményeket összefogó szervezet ${ }^{57}$.

\section{DMP - Data Management Plan}

Magyarul adatkezelési terv. Gyakran a kutatástámogató szervezetek kérik kutatási projektekhez - az NKFIH is kér ilyet.

Mire kell kitérnie egy adatkezelési tervnek?

- Adatok jellege, formátuma, mennyisége;

- hosszú távú megőrzés, egyedi azonosítók;

- kockázatok (pl. etikai, személyes adatok kezeléséből adódó);

- hozzáférhetőség, felhasználási licenc;

- adatkezelés esetleges költségei;

- adatok értéke, felhasználhatósága más projektekben;

- nyilvános, projekten kívüli adatok használata;

- és minden egyéb releváns körülmény.

Az adatkezelési terv élő dokumentum, a projekt során folyamatosan frissíteni kell!

A LIBER összeállított egy katalógust az adatkezelési tervekről (Data Management Plan Catalogue ${ }^{58}$.

\section{DDP - Domain Data Protocol}

Az adatkezelési terv alternatívája: a szakterületi adatkezelési protokoll ${ }^{59}$. A Science Europe javaslata.

57 https://openscience.hu/hunor/ (utolsó megtekintés: 2021. 09. 23.)

58 https://libereurope.eu/working-group/research-data-management/plans/ (utolsó megtekintés: 2021. 09. 23.)

59 http://www.scienceeurope.org/media/nsxdyvqn/se_guidance_document_ rdmps.pdf (utolsó megtekintés: 2021. 09. 23.) 


\section{Nyílt PUblikÁLÁSI SZOFTVEREK ÉS PLATFORMOK (OJS, OCS, OMP)}

Több nyílt forráskódú folyóirat-működtető szoftver létezik ${ }^{60}$. Mi itt a hazánkban is leggyakrabban használt, a Public Knowledge Project által létrehozott Open Journal Systems-t említjük, illetve „testvéreit”, az Open Conference Systems-et és az Open Monograph Press-et. Részletesebben lásd Holl és Bilicsi (2019) cikkét. Jeleznünk kell, hogy jelenleg az OCS elhanyagolt, frissítésre szoruló program.

Az OJS támogatja az OAI-PMH protokollt, a DOI regisztrációt.

\section{CoreTrustSeal}

A repozitórium-minősítés általánosan elfogadott, teljesíthető követelményeket támasztó rendszere a CoreTrustSeal ${ }^{61}$. Korábbi minősítési rendszerek fejlődésével, összeolvadásával jött létre. A tanúsítványok hierarchiájában ún. alapszintű tanúsítványt ad. A kiterjesztett és formális szintek az ISO 16363 vagy a DIN 31644 szerinti minősítést igénylik, az előbbi önminősítés, az utóbbi formális minősítési eljárás során ${ }^{62}$. (A rendszer kidolgozása idején az alapszintű tanúsítványt Data Seal of Approval-nak hívták. Ebből fejlődött ki a CoreTrustSeal.)

\section{DOAJ - Directory of Open Access Journals}

A DOAJ ${ }^{63}$ egyszerre nyilvántartás, minősítő szervezet és aggregátor.

60 http://edutechwiki.unige.ch/en/Journal_management_software (utolsó megtekintés: 2021. 09. 23.)

61 https://www.coretrustseal.org/ (utolsó megtekintés: 2021. 09. 23.)

62 http://www.trusteddigitalrepository.eu/Trusted\%20Digital\%20Repository.html (utolsó megtekintés: 2021. 09. 23.)

63 https://doaj.org/ (utolsó megtekintés: 2021. 09. 23.) 


\section{DOAB - Directory of Open Access Books}

Nyílt hozzáférésű könyvek listája ${ }^{64}$. Az OAPEN és az OpenEdition közös vállalkozása (további szervezetekkel együtt).

\section{SCOSS - Global Sustainability Coalition for Open Science Services}

A nyílt tudományt támogató infrastruktúrák finanszírozását támogató kezdeményezés ${ }^{65}$.

\section{COMPASS}

A hazai előfizetett elektronikus források lelőhely-adatbázisa, amit az EISZ biztosít. Az erőforrásról bővebb információt Sütő (2019) ad. A COMPASS+ az adatbázisok előfizetésével kapcsolatos döntéstámogató eszköz.

\section{MTMT}

A hazai kutatási bibliográfia. Működéséről bővebb leírást Holl (2021) ad.

Az MTMT nyilvános felületével ${ }^{66}$ is szolgálja a nyitottság elvét, valamint felvihetők a tudományos művek szabad hozzáférésű változatainak elérhetőségei (zöld és arany lakat jelzés), illetve készíthetők Open Access statisztikák.

\section{TÖRVÉNYI (ÉS EgYéB) SZABÁLYOZÁs MAGYARORSZÁGON}

- A PhD dolgozatok szabad eléréséről: 201l. évi CCIV. törvény a nemzeti felsőoktatásról (53/A. §. (2)).

64 https://www.doabooks.org/ (utolsó megtekintés: 2021. 09. 23.)

65 https://scoss.org/ (utolsó megtekintés: 2021. 09. 23.)

66 https://m2.mtmt.hu/gui2/ (utolsó megtekintés: 2021. 09. 23.) 
- A költségvetési forrás felhasználásával készült publikációk bibliográfiai adatainak kezelése az MTMT-ben: 1994. évi XL. törvény a Magyar Tudományos Akadémiáról (19/A. \$); 2011. évi CCIV. törvény a nemzeti felsőoktatásról (26. § (1)).

\section{IRODALOM}

Farkas és Sándor 2020

FARKAs Richárd, SÁNDOR Ákos, Digitalizált tartalmak közös keresője VuFind alapokon az SZTE Klebelsberg Könyvtárában = Networkshop 2020. Országos Online Konferencia, 2020. szeptember 2-4., Budapest, HUNGARNET Egyesület, 22-32. https://doi.org/10.31915/NWS.2020.3

Gibney 2016

Gibney, Elizabeth, Open journals that piggyback on arXiv gather momentum, Nature, 530, 04 February 2016, 117-118, https://doi.org/10.1038/nature.2015.19102

Görögh 2017

GöRÖGH Edit et al., OpenUP D3.1 Peer-review-landscape-report, 2017. https://doi.org/10.5281/zenodo.2557272

Holl 2009

Holl András, Karácsony Gyöngyi, Harangi Gabriella, Cserbák Márton, Teljes szövegü publikációk cseréje repozitóriumok között - a SWORD protokoll tesztelése az MTA Könyvtárában és a Debreceni Egyetem Könyvtárában = Networkshop 2009, 2009. április 15-17., Szeged. http://real.mtak.hu/65206/

Holl és Bilicsi 2017

Holl András, BILICsi Erika, ORCID - egy újabb szerzői azonositó tudományos közleményekhez, Könyvtári Figyelő, 2017/3, 346-350. http://real.mtak.hu/65517/ 
Holl 2018a

Holl András, Nyílt hozzáférés - elönyök, lehetôségek, feladatok, veszélyek = Erdélyi évszázadok: a kolozsvári Magyar Történeti Intézet évkönyve, Kolozsvár, Egyetemi Műhely Kiadó, 2018, 75-85.

http://real.mtak.hu/92213/

Holl 2018b

Holl András, A nyílt kutatási adatok kezelésének három oldala = Networkshop 2018 konferenciakiadvány, Budapest, HUNGARNET Egyesület, 2018, 59-63. https://doi.org/10.31915/NWS.2018.8

Holl 2018c

Holl András, Újragondolt repozitóriumok = AgriaMedia 2017, XII. Információtechnikai és Oktatástechnológiai Konferencia és Kiállítás, ICI-15 Nemzetközi Informatikai Konferencia, Eger, 2017. október 1113., Eger, Líceum Kiadó, 2017.

http://publikacio.uni-eszterhazy.hu/2343/

Holl és Bilicsi 2019

Holl András, Bilicsi Erika, Nyilt publikálási szoftverek és platformok = Networkshop 2019., Budapest, HUNGARNET Egyesület, 54-60. https://doi.org/10.31915/NWS.2019.7

Holl 2020a

Holl András, A kutatási adatok dokumentálását elősegitő szoftverek = Networkshop 2020, https://doi.org/10.31915/NWS.2020.1

Holl 2020b

Holl András, Parazita folyóiratok, Tudományos és Műszaki Tájékoztatás, 67 (7-8), 472-475.

https://tmt.omikk.bme.hu/tmt/article/view/12679 
Holl 2020c

Holl András, Milyen úton érjük el a tudományos közlemények nyílt hozzáférhetôségét?, Magyar Tudomány, 181 (1), 121-131.

https://doi.org/10.1556/2065.181.2020.1.14

Holl 2021

Holl András, A Magyar Tudományos Müvek Tára - alapvetô információk és múködési alapelvek, Magyar Tudomány, 182 (1), 81-89.

https://doi.org/10.1556/2065.182.2021.1.12

Lendvay 2020

Lendvay Miklós, Országos Könyvtári Platform - központi könyvtári szolgáltatások együttmüködő rendszere = Networkshop 2020.

https://doi.org/10.31915/NWS.2020.10

Micsik és Gárdos 2014

Micsik András, GÁrdos Judit, Tudományos repozitóriumok az MTA-ban: a KDK és a SZTAKI tanulságai = Informatika a felsőoktatásban, 2014. 08. 27-2014. 08. 29, Debrecen, Hungary.

https://eprints.sztaki.hu/8017/

Mons 2018

Mons, Barend, Data Stewardship for Open Science, CRC Press, 2018.

Nagy 2018

NAGY Gyula, A könyvtárak szerepe a digitális és elektronikus tananyagok archiválásában $=$ The role of libraries in archiving open educational resources = Networkshop 2018 konferenciakiadvány, Budapest, HUNGARNET Egyesület, 91-97.

https://doi.org/10.31915/NWS.2018.13

Ross-Hellauer 2017

Ross-Hellauer, Tony, What is open peer review? A systematic review, F1000Research, 2017, 6:588.

https://doi.org/10.12688/f1000research.11369.2 
Schapira 2019

SchapiRa, M. et al., Open laboratory notebooks: good for science, good for society, good for scientists, F1000Research, 8.87.

https://doi.org/10.12688/f1000research.17710.2

Sennyey és Kokas 2020

Sennyey Pongrácz, Kokas Károly, Digitális ökoszisztéma a könyvtári katalógusból? Egy texasi könyvtári kísérlet és tanulságai = Networkshop 2020. https://doi.org/10.31915/NWS.2020.2

Suber 2012

Suber, Peter, Open Access, MIT Press.

https://www.dropbox.com/s/5cxsyzs58a5yx5q/9286.pdf?dl=1

Sütő 2019

Süтő Péter, $A z$ elektronikus szakirodalmi információforrások hazai lelóhelyadatbázisa, a COMPASS = Networkshop 2019, Budapest, HUNGARNET Egyesület, 150-156.

https://doi.org/10.31915/NWS.2019.19

Tarcsi 2019

TARCsi László, A hazai MOOC portálok áttekintése, Opus et Educatio, 6. 1. https://doi.org/10.3311/ope.293

Wilkinson 2016

Wilkinson, Mark D. et al., The FAIR Guiding Principles for scientific data management and stewardship, Scientific data, vol. 3., 15. March 2016. https://doi.org/10.1038/sdata.2016.18 


\section{Open Science \\ NYÍLT TUDOMÁNY MAGYAR SZEMMEL}


A Magyar Tudományos Akadémia Könyvtárának Közleményei Publicationes Bibliothecae Academiae Scientiarum Hungaricae

$45(120)$
UJ SOROZAT

SOROZATSZERKESZTő

GaÁlné Kalydy Dóra 


\section{Open Science \\ NYÍLT TUDOMÁNY MAGYAR SZEMMEL}

Magyar Tudományos Akadémia

KöNYVTÁr ÉS InFORMÁcIÓs KözPONT

BUDAPEST 2021 


\author{
Szerkesztette \\ GaÁlné Kalydy DóRA \\ Anyanyelvi lektor \\ MóNOK MÁRIA \\ Az irodalomjegyzékeket készítette \\ BudAI-KirÁLY TÍmEA \\ Tipográfia és tördelés \\ VAs ViKTória \\ ISBN 978-963-7451-73-7 \\ ISSN 0133-8862 \\ DOI 10.36820/MTAKIK.KOZL.2021.OpenS
}

Felelős kiadó: az MTA Könyvtár és Információs Központ főigazgatója

Nyomta és kötötte az Alföldi Nyomda Zrt., Debrecen

Felelős vezető: GYöRGy GÉzA vezérigazgató

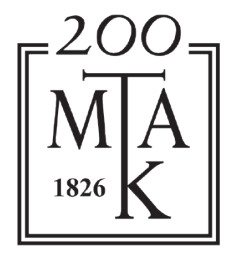

Megjelent a Nemzeti Kulturális Alap támogatásával

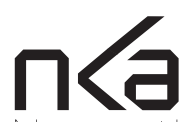

Nemzeti Kulturális Alap 


\section{TARTALOM}

\section{Monok István}

Cui bono, seu cui prodest?

Holl András

A tudományos szakkönyvtárak és a nyílt tudomány

(Open Science)

GaÁlnÉ Kalydy Dóra

A kiadókkal kötött Read and Publish szerződések, és a nyílt hozzáférésű publikálás hazai lehetőségei

Soós SÁndor, Kiss AnNA

Az „Open Access-előnyök" megnyilvánulása

a hazai tudásprodukcióban: bibliometriai hatásvizsgálat

61

\section{GaÁlné Kalydy Dóra}

A közösségi tudomány

\section{Tiberius Ignat}

What motivates us to develop the

Focus on Open Science series?

\section{Hoczopán Szabolcs, Molnár Tamás}

Az egyetemi könyvtárak szerepe a nyílt tudomány

mozgalom elterjesztésében

\section{Holl ANDrás}

Az MTA KIK gyakorlata a nyílt tudomány támogatásában $\quad 161$

A kötetben szereplő tanulmányok szerzői

A Magyar Tudományos Akadémia Könyvtárának

Közleményei, Új Sorozat közelmúltban megjelent kötetei 